\title{
STRADDLING THE BOUNDARY: THE CASE OF MAHALI CHRISTIANS IN TERMS OF THEIR SOCIO-CULTURAL ADJUSTMENT, IN TWO MAHALI VILLAGES IN BANGLADESH
}

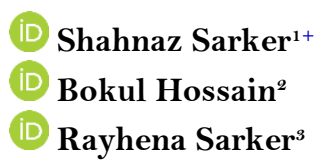

\author{
'Department of Sociology, Jagannath University, Dhaka, Bangladesh \\ Email:shahnazsarker@yahoo.com Tel:+8801710919760 \\ ${ }^{2}$ Department of Sociology, University of Rajshahi, Rajshahi, Bangladesh \\ Email:bokulhossain2625@gmail.com Tel: +8801759584280 \\ ${ }^{3}$ Department of Anthropology, Darussalam University, Brunei \\ Email:rayhenasarker@yahoo.com Tel:+6738873559
}

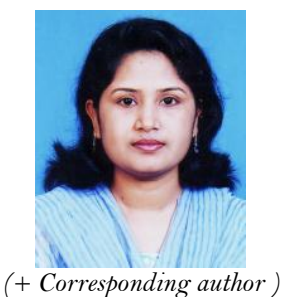

\section{ABSTRACT}

Article History

Received: 12 March 2018 Revised: 9 April 2018 Accepted: 13 April 2018 Published: 16 April 2018

\section{Keywords}

Mahali

Ethnic community

Socio-culture

Religious syncretism

Christianization

Cultural Change

Bangladesh.

\begin{abstract}
In this study we selected a small ethnic group named Mahali living in the villages Pachandar and Mondumala of Barind track at Rajshahi in the north-western part of Bangladesh along with the mainstream individuals. Those two villages are entirely occupied by homogenous people of Mahali who practice their traditional lifestyle accompanied by Christianity. In this context, we have tried to explore the religious syncretism of the Mahali Christians regarding their ethnic background, socio-economic status, power structure and their belief systems. We also identify the process of acculturation that took place among the Mahalis after Christianization and that resulted in a number of social changes through decades, thus turning the Mahali culture into a state of transition. In addition, we have also made some recommendations on this issue based on the findings having from the study
\end{abstract}

Contribution/ Originality: This study is one of very few studies which have investigated about a Bangladeshi ethnic community, Mahalis, who are in identity crisis in Bangladesh. This investigation contributes the recent primary data regarding socio-economic profile of them. However, this work will also provide a concise picture of socio-cultural transition after Christianization.

\section{INTRODUCTION}

\subsection{Background of Study}

There is a range of tribal people, namely Santals, Oraon, Rajbanshi, Garo, Chakma, Monipuri, Mag, Murang, Tiprasand, Turi, Pahan, Mahali, Gorrat and so on lived in Bangladesh. Among them more than seven tribal communities were lived in the region of Barind track in Rajshahi, the north-western part of Bangladesh. Generally, most of the ethic individuals had been migrated from one place to another by usually crossing the political boundary to overcome either their crisis of residency or economic pursuits so as to get stable life. The reason behind their migration such as Santal, Munda, Oraon people and the Mahalis encountered the same turn. For instance, the Oraons (Ray and Biswas, 2013) had partially migrated to India from Bangladesh (then East Pakistan) in search of new jobs with a hope that the moneylenders and Zaminders (landlords) of that locality will help them to combat their crises. However, the earliest information of those communities were most probably given by the investigators 
Dalton and Risley (Dalton, 1872; Risley, 1891) who insight the pattern of ways of lives of those communities. Ahsan Ali gives detail information of an ethnic community of Barind track in his book- The Santals of Bangladesh (Ahsan, 1998) where the focus of Ahsan's study was on the social change among the Santals living in the northern part of Bangladesh. He also studied the Barind region, the socio-economic-politico situation of the other ethnic communities. The Paharias (Gomes, 1988) by Stephen G. Gomes, is a study of another ethnic community of Barind trac, which is an ethnographic work. In his book, he includes different aspects of Pahari way of life in Bangladesh, their origin and tradition, their life style, their socio-economic-political organization etc. The history of tribal studies in Bihar was given a turning point by the zealous interest in the subject by the late Rai Bahadur S.C/Roy who under took detailed monographic studies of some of the tribes of Chotonagpur (Roy, 1912). In his study he marked a beginning of a full length study of a tribe in Chotonagpur an Indian national. Roy presents on exhaustive picture of the life, culture changes and the history of the Munda tribes. Going through literature in depth we found a very little information regarding Mahali community, who are living in the Barind track of Bangladesh. In this regard, our present investigation has been focused on this ancestral population of Bangladesh.

\subsection{Historical Background of Mahali Community}

Mahalis, one of the earliest inhabitants in the northern part of Bangladesh (Fig-1), are considered to be the descendants of the non-Aryan Dravidian stock (Rao, 2006). Regarding the ethnic origin of Mahalis with the reference to the Gananapustak of the Holy Bible-stanza no. 3:20, the Mahalis are known as the children of Marari. In the same stage, they are considered as descendants of the Labian group, a priestly group. But it is not yet confirmed that these Mahalis as mentioned by Holy Bible and the present Mahalis are alike. However, there is a clan similarities between Santals and Mahalis. Alike the Santals, the Mahalis are divided into 12 same clans (Fig.6). Both the Mahalis and the Santals is clan exogamous and they use these clan names in their titles which their ancestor group can easily be identified. Moreover, there is about $80 \%$ similarity between the Santali and Mahali language. So, it can be assumed that the Santal and the Mahalis are of same origin although it is not yet confirm but the mythology may support it. According to mythology (O’Malley, 1938) about Mahali’s ethnic origin a long time ago there was a Santal region in the country of Chompagar whose king was known as Kiscu. In an unavoidable circumstances, some of the Santals were bound to escape from the country. After getting out from the country, they moved around to different places and ultimately settled in a place which seemed to be a part of the present Bihar and it may also be guessed that from then onwards, that place has been named Santal Pargana from where they have migrated to the northern part of Bangladesh. The most interesting part of the mythology is that they were the priestly groups, which resembles the Bible's saying that the Mahalis are descendant of the Labian group.

The term Mahali comes from the word Moholi that seems to originate from the word Mohal. From the very beginning, there were not sufficient crafts maker so every Mahalis were engaged in selling their hand-made bamboo products in a certain region which are called Mahal. As they supply products from Mahal to Mahal, they are called Mohali and later turned into Mahali. Their physical traits are characterized by medium statured, narrow headed people. They have had dark skin color, approaching black, and wavy or curly black hair. They had fat-lips, flat noses, like the inhabitants of modern-day Oceania and parts of Africa.

The Mahali of Bangladesh are related to a much larger group called Santal, both groups being of the protoAustraloid race and speaking related languages. They are mainly migrated from Dumka district in the state of Bihar and settled here in the early 1900 (Dalton, 1872; Risley, 1891; O’Malley, 1938). During that period this area of Barind tract was completely covered with forest. They came here, cut all the forest land, built houses and started dwelling here. They were, in fact, nomadic people and so, moved around different places for their lives and livings. It is generally assumed that the Santals and the Mahalis always do live side by side. The main reason may be that the Mahalis are the only producer of bamboo-made items such as dala, kula etc. without which Santal marriage can't 
take place. And therefore, it may be assumed that the Mahalis migrated to Bangladesh and settled here as soon as the Santals did.

\subsection{Christian Evangelization}

During their stay in India, some of the Mahalis started going to church for prayers with a view to getting baptized into Christianity. According to the Mahalis, in the beginning of the $20^{\text {th }}$ century, when they migrated to this country and settled here permanently, Father Dilcorn used to travel here by horse from Krisnanagar of India and managed to baptize many of them into Christianity although the exact time or year yet to be identified. But it is assumed that Beniduar diocese was the first to contribute in getting the Mahalis baptized into Christianity and gradually, thereafter, many more Mahalis were baptized under different dioceses at different areas and villages.

The first Christian missionaries in the north Bengal was established in Begunbari and within in $29^{\text {th }}$ January, 1902. A man from the Munda community (Hoffman, 1950) named Mr. Gabriel Tapna migrated from Chotonagpur of India (Roy et al., 1980) to settle in Begunbari and within a short time, he set up an organization to bring a father over there. Then father Rocca came to their mission. Later on, Mahali from different places get baptized into Christianity. The Mahalis of Mondumala were baptized by father Alexander and father Sebastian of Rohonpur mission within 1950-52. The Mahalis claim that they are the first who converted to Christianity. At present all the Mahalis of that region have converted to Christianity.

Though they introduced themselves as Mahalis not Bengalis, but at present time they celebrate the important occasions of the Bengalis. They also celebrate $26^{\text {th }}$ March (the independent day of Bangladesh) and $16^{\text {th }}$ December (the victory day of Bangladesh). They arrange different sports on that day.

The Mahali, however, live in villages which are separate from Santali villages as well as separate from Bengali villages. The Mahali of Bangladesh are nearly 100\% Christian. Furthermore, they are almost all Catholic and are mostly living in (Fig.1) Sylhet, Rangpur, Chittagong, and Rajshahi. Moreover, a few of them are residing at Khulna and Dhaka.

As a researcher we have the best chance to identify fertile problems, which may stimulate more adequate models of socio-cultural reality. The common people think that the Mahalis have lost their traditional norms after Christianization. To mitigate the confusion we have chosen the Mahali group of people who live in Mondumala and Pachandar of Tanore Thana in Rajshahi district.

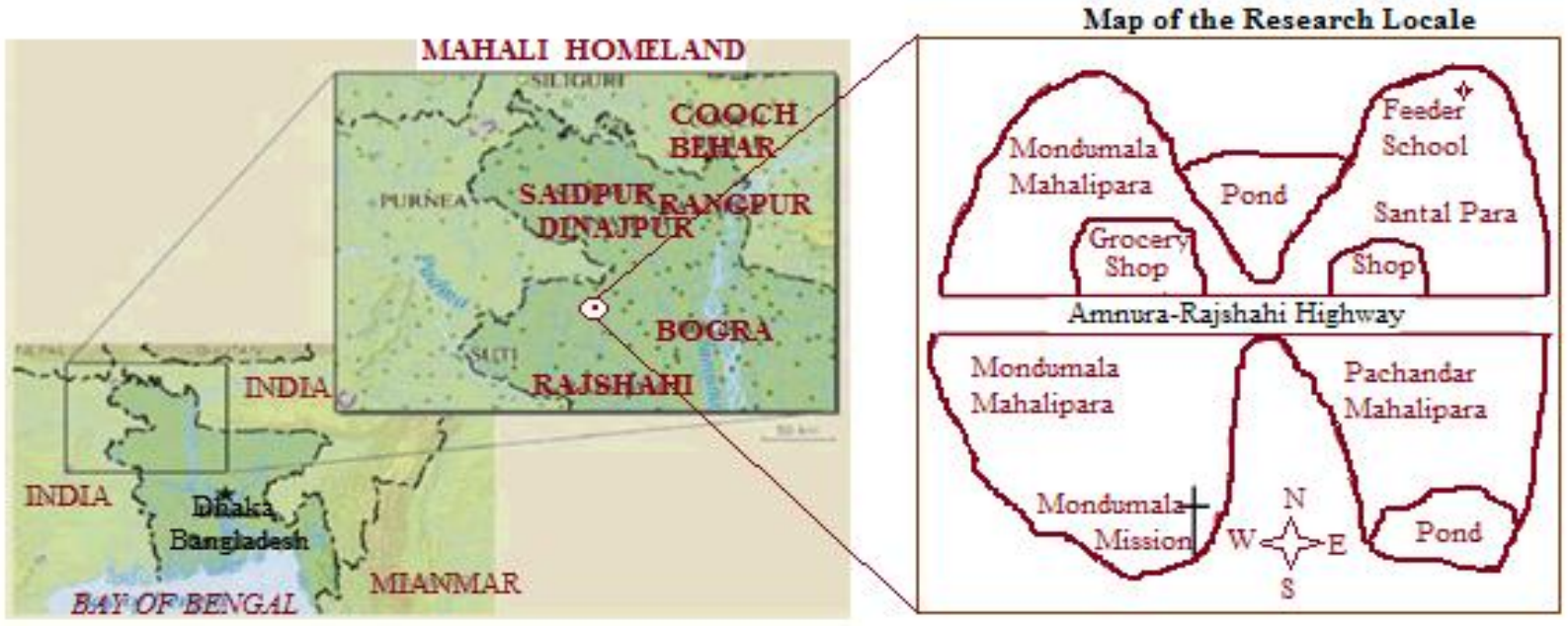

Fig-1. Mahali homeland in Bangladesh and the map of the research locale.

Source: Thana Revenue Office (Geography of Tanore Thana, Rajshahi, Bangladesh)

\subsection{Objective of Study}

These Mahali peoples came from Manbhum, Birbhum and Chotonagpur (Roy, 1912; Roy et al., 1980) to the Barind track. They were brought by the British Govt. to clean the bush area. Though they cleaned the area but they 
had not got any land. They were helpless from that period. Although the Mahali people live side by side the mainstream people of Bangladesh, but they are not treated as the part of majority people.

Bangladesh govt. also does not give them proper opportunity like the mainstream people. They don't get much help for their livelihood. For this reason they don't hesitate to take help from different non-government organizations. Christian missionaries are one of them. These missionaries give all types of help for their subsistence, but the condition is that they would convert to norms, values, behaviors etc. The confusion of the mainstream people emerges at that point. It seems to them that the Mahalis have forgotten their own tradition and they have received the Christian values. Our study will assure that point and try to prove that how the Mahalis affirm that one as Mahali and at the same time have belief in Christianity. In asserting this conviction the Mahali Christians deny the existence of the boundary that for so many people categorically divides Mahalihood and Christianhood into two distinct identities. The research will analyze the construction of culture within the framework of that boundary. The research will assume a constructionist view, i.e. that individuals and groups make choices in the ways in which they define themselves.

This study cannot be claimed to be an in-depth and comprehensive one, however this descriptive research may give the way for the enthusiastic researchers to come forward for further studies on the Mahalis.

As there is not enough published study which reveals in-depth information about this ethnic community of Barind tract, for this reason it is very important to know about the Mahali people of Bangladesh. So it is more likely a potential problem for the Government to take any development programs for them. This study was planned in this connection and will describe all the information intensively. It will also give a detail description about the Mahali people of Barind tract, which will help the Government to take necessary steps for them.

\section{METHODOLOGY}

Field survey for this study was conducted in two different Mahali villages namely Pachandar and Mondumala of Tanore Upazila at Rajshahi District in 2016. Those two villages are ten miles away from the Tanor upozela headquarter and Tanor is $40 \mathrm{~km}$ from Rajshahi district. The Mahali villages under study contain a total Mahali population of about 500. In Pachandar the total Mahali population was 238 and in Mondumala 262. Both qualitative and quantitative data and both empirical and secondary data have been used in this article. Empirical data had been collected using the social survey method and through face-to-face interviewing with a structured interview schedule from the respondents. The fieldwork of the study was conducted for more than two months (from October 2016 to November 2016), a sample of 50 respondents have been purposively selected from the villages. We made casual visit to the villages to have a better understanding of their traditions and changes.

\section{RESULTS AND DISCUSSIONS}

\subsection{Housing Pattern}

The houses of the study area are made by mud. The surface of the house is made of mud and roof is covered by tin and hay. The Mahalis of Tanor Thana make small houses with one door. Those who are rich make two stored building of mud. Their houses are net and clean. They make the fence of the house with the mixer of mud, dust of paddy and jute fiber in such a way that looks like a construction of concrete. Some Mahalis create different types of design over the mud made inner and outer surface.

\subsection{Food}

After Christianization huge changes occurred to the food habits of the Mahalis. Before Christianization they used to eat pig, mouse, dead hen-duck, crab, mongoose, snails, oyster etc. But now their food habit is as like as typical people. In this context, there are some differences between one generation to another. The aged persons are interested to intake traditional food but the youngsters are highly fond of modern foods. 


\subsection{Education and Language}

Most of the Mahalis were illiterate in the recent past. For this reason about 40 year old Mahali people are illiterate (about 46\%) today. But at present time the scenario has been changed for the influence of the missionaries. The Mahalis try to send their children to school and highly interested to give them higher education. There is a feeder school (Photograph 1) up to class three in Pachandar, which is run by the mission. They also practice Mahali language (using Mahale Okkhor) along with the national curriculum. There are two high school and one college in those villages. Mahalis get help from the mission for buying books and for form-fill-up and it also distribute books to the primary students. But recently they don't get sufficient help from the mission and blamed the father of the mission. In this case, the Father said that by giving this type of help (food, housing, education, and treatment) the Mahalis become dependent. That's why they give them partial support to make them independent. The Table 1 shows the literacy level of two villages by gender.
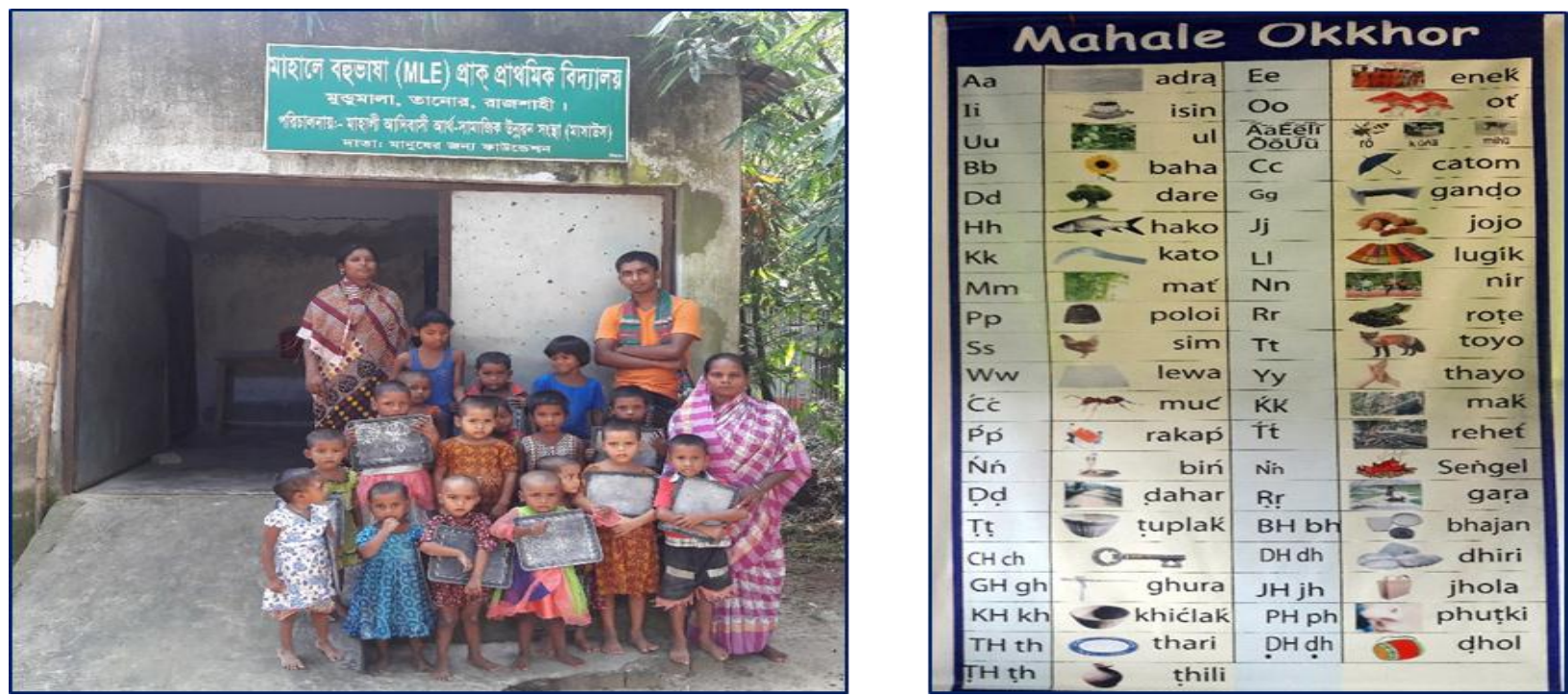

Photograph-1. Mahali School and Alphabet.

Table-1. Educational status of Mahali people

\begin{tabular}{l|l|l}
\hline Educational qualification & Respondent & Percentage (\%) \\
\hline Illiterate & 23 & 46 \\
\hline Primary education & 12 & 24 \\
\hline Secondary education & 10 & 20 \\
\hline Higher secondary education & 0 & 0 \\
\hline Other & 5 & 10 \\
\hline Total & 50 & 100 \\
\hline Source: Authors Primary Data Literacy level of Mahali People) & \\
\hline
\end{tabular}

\subsection{Occupation}

The Mahalis mainly (about 76\%) worked as craftsman (Photograph 2) and farmer who make various products by bamboo (Table 2) and do agricultural works respectively. However, many of them work as agricultural wage labor. 


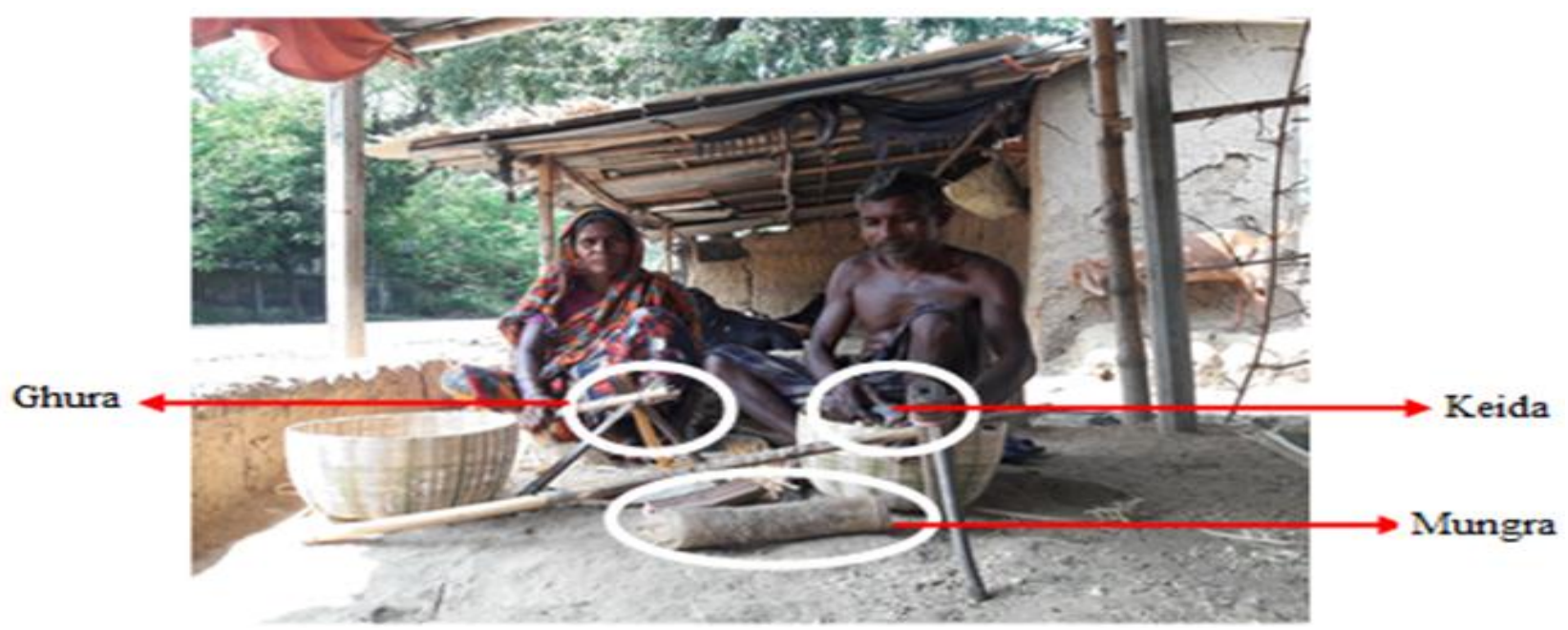

Photograph-2. Mahali couple busy for making bamboo product.

Table-2. Various products made by bamboo.

\begin{tabular}{l|l|l|l}
\hline In Bengali Word & In Mahali Word & In Bengali Word & In Mahali Word \\
\hline Dali & Khazla & Chaluni & Chala \\
Kula & Hata & Dhaki & Daki \\
Pakha & Bini & Khalai & Khaloi \\
Jhaka & Fatia & Lobon dani & Bulong tungki \\
Chatai & Dharai & Batna & Fatia \\
Dhakni & Dubla & Khocha & Dhumi \\
& & Topa & Tapa \\
\hline
\end{tabular}

Source: Authors Field Works ( Mahali Language)

There are very few service men (8\%) and businessmen (6\%) in Mahali villages. The people who are engaged in other occupation rather than traditional one are not interested in crafts making, though there number is very rare. The following bar chart (Fig.2) reveal the percentage of various professions among the Mahalis.

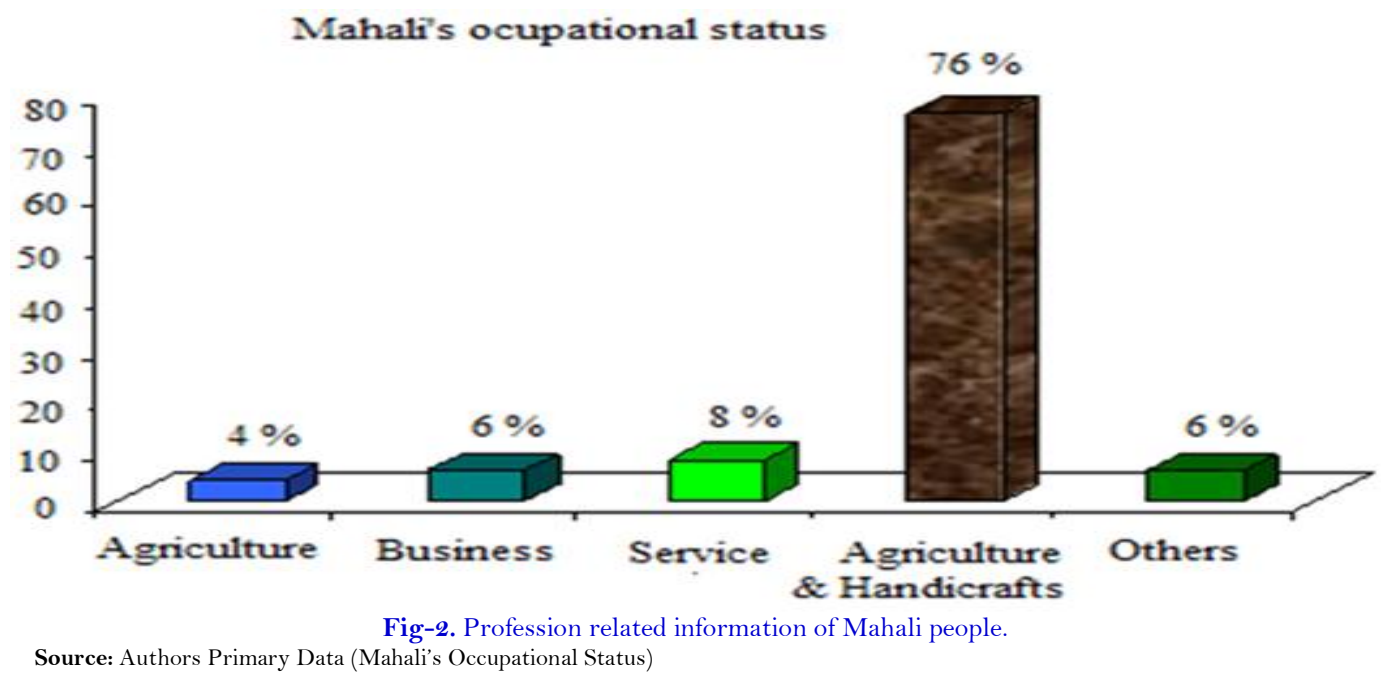

\subsection{Health and Sanitation}

Water supply is a vital problem of the study area. Few years ago the Mahali people used tube well water. But recently the water surface of Barind Tract is so low that there is no water flow in the tube well. That's why The Varendra Bohumukhi Development Authority supply water through deep tube well. The local people call it Tap. Lack of sufficient pure drinking water they face so many medical problems and they bear an ill-health. 
Sanitation problem is a great problem in those villages even in modern times most of the people have not the sanitary latrine. As a result, they normally relieve themselves in the open field. Though they have sanitation problem but they have advanced medical facilities for all types of diseases provided by the hospital established by the mission. However, if the diseases not cure then they go to the hospitals and get free treatment sowing certificate given by the mission hospital. Even though, when they go to the govt. hospital they get extra facilities along with govt. treatment.

\subsection{Monthly Income}

In order to get the economic and social status of Mahali people we collect the information related to the monthly income of Mahali people which has been depicted in the bar diagram (Fig. 3). The monthly income of about $51 \%$ of total respondents was 6000 to 8000 Tk. while there are not a single person whose monthly income is more than $12000 \mathrm{Tk}$.

\section{Monthly income related information of respondents}

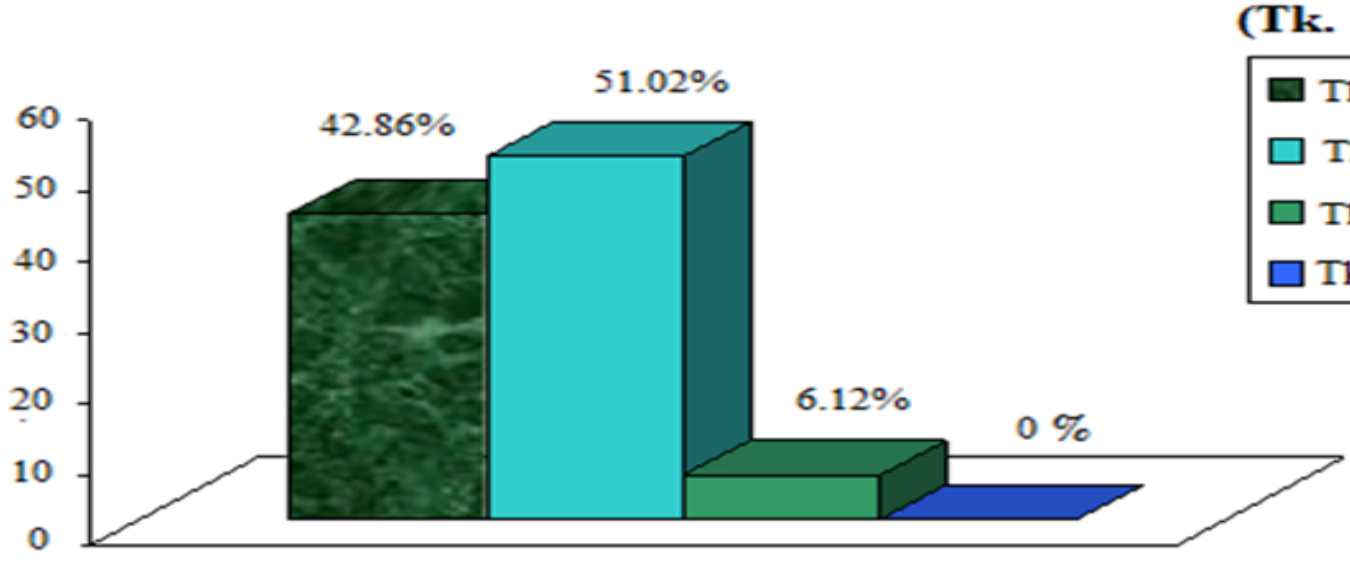

Fig-3. The information regarding monthly Income of Mahali people.

Source: Authors Primary Data ( Income of Mahali People)

From this data it can be easily understood that most of the Mahalis are living under poverty since the per capita income of Bangladeshi people is $\$ 1,610$ in the FY 2016-17 according to Bangladesh Bureau of Statistics (BBS). The discrimination in monthly income among the Mahali people is not only due to the land assets but also number of earning people in a family. However, it is worthless to mention here the monthly spent of them because almost all of the respondents have been answered that it is very difficult to bear their familial cost by their earnings. Therefore, they have to take loan from different NGO's and banks, which are especially non-government one, so as to meet their fundamental needs.

\section{SOCIAL ORGANIZATION}

Study of social organization of Mahali society deals primarily with the significant grouping of individuals. With the help of that group or association they satisfy their need and such associations are family, marriage, kinship and clan organization.

\subsection{Family}

There are three types of family among the Mahalis such as nuclear, extended and joint family. Among the types most of the families (about 90\%) are nuclear family, whereas extended and joint families are below $10 \%$.

The potential reasons, behind the Mahalis prefer to construct a nuclear family, are economic pressure, female discord, marriage, lack of accommodation, father's death, conflict among brothers and impact of modernization. 
The Mahalis are mainly patriarchal family, where male are all in all in the family but in recent time female also play important role as man do, except marketing the product. For this reason they have authority and can express their commitment in familial decision-making. However, female have no entrance in social decision-making. They cannot participate in the Salis to solve the communal problems as it is the norms of social structure, in the other words, the social norms of their country do not permit the women to engage in those activities.

The decent group membership is best on linked through either the paternal and maternal line. In Mahali society, membership in a family is identified through paternal line. In this paternal line inheritance goes through father to son as illustrated in the following diagram (Fig.4).According to the law of inheritance of property of Mahali Christians go to the sons. If husband dies and had no sons then the wife will get the property and then it goes to her daughters.

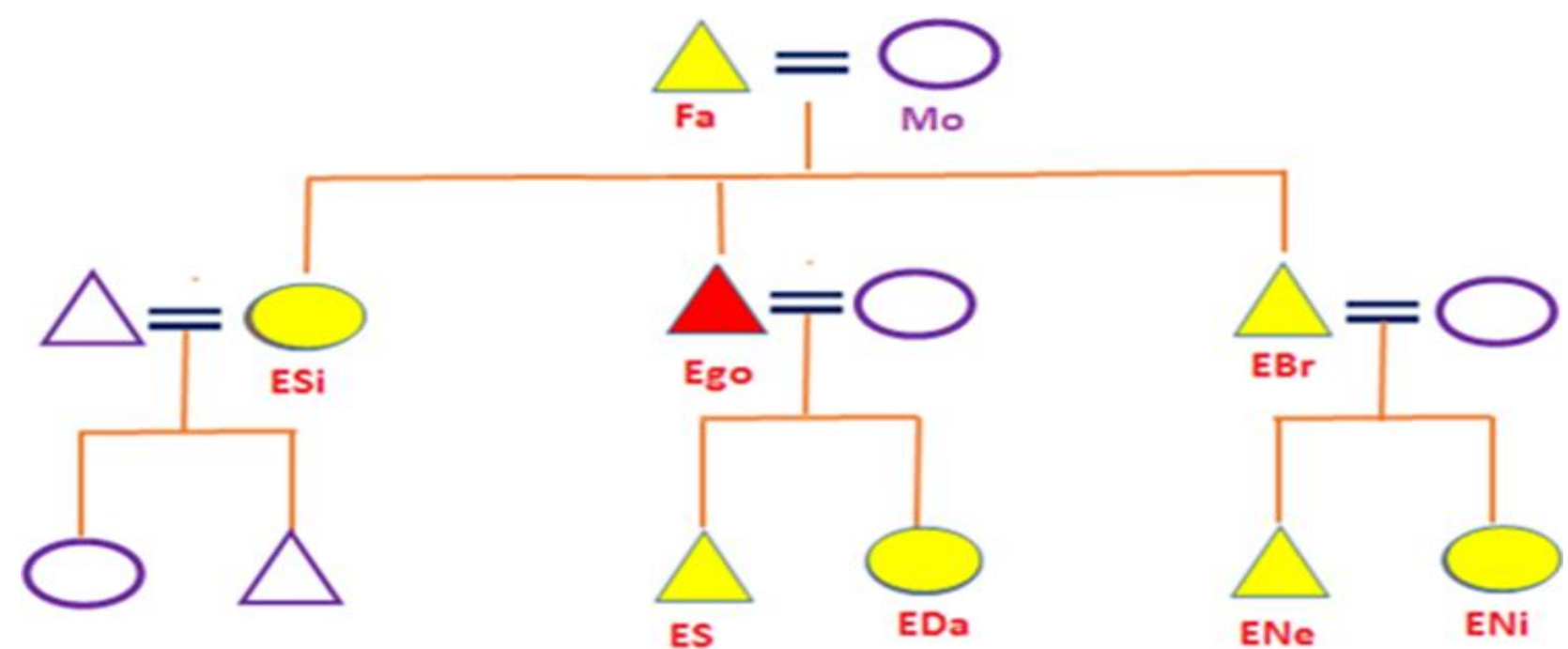

Fig-4. Diagram of Patrilineal Descent system [NB: Fa = Father, Mo=Mother, Si= Sister, Br=Brother, ESi= Egơ's Sister, EBr= Egơ's Brother, ES= Ego's Son, EDa $=$ Ego's Daughter, ENe $=$ Ego's Nephew and ENi = Ego's Niece ].

Source: Authors (Following Book: Ember and Ember (1994))

\subsection{Marriage}

It means a union between a man and a woman, which is permitted by the society. It is very important in every society to control the sexual crime. It can establish peach in the society and the basis of elementary family. A new relationship is established between two families through marriage. To a Mahali family marriage is not only for sex gratification, but also a social need for propagation of families and economic co-operation.

Investigation in Mahali villages reveals that there are different forms of marriage in their society. The main types are Monogamy, ties between one man and a woman which is most common and widely accepted among the Mahali group of people and Polygamy, a male and a female marry more than one, which is strictly prohibited among the Mahalis as they have converted to Christians. But it was permitted before Christianization. Settle marriage is more frequently seen among them but love marriage can also take place with the approval of the parents.

Among Mahali people there are a few marriage types, which are the outcome of the break in the marriage tie either by divorce or by mutual agreement. This gives rise to four types such as Levirate-Levirate means marrying the widow of a deceased brother. In this case the younger brother must be a bachelor. Sororate: Marrying the deceased wife's sister is allowed among the Mahalis. However senior sororate is strictly prohibited, as wife's elder sister is the most respectable person to her younger sister's husband. Therefore, the marriage with wife's younger sister is permissible. Widow/Widower marriage: Widow/Widower marriage is frequently permitted among the Mahalis. This ceremony is performed when one's husband or wife dies. A widow woman normally marries a widower, but she also can marry a bachelor if he agrees in that marriage. Though this type of marriage is permitted 
by the society, but they do not do it because they feel that it is like polygamous marriage, which is restricted among them. Remarriage: It is not seen among the Mahalis because divorce is restricted among them. Though it was noticed before Christianization, but is not prevailed in modern time.

There are various rules of marriage among the Mahali people. These are as follows-

1. Monogamy is normal rule of marriage in Mahali society;

2. Parallel cousin marriage is strictly prohibited among them;

3. Cross-cousin marriage is also forbidden among them;

4. The Mahali cannot marry in the same clan;

5. The Mahali are totally clan exogamous. That means a hemrom cannot marry another hemrom.

6. The Mahali can marry a Santal, who is not of the same clan and is Christian.

7. A Christian Mahali by no means can marry someone other than Christian. If a Mahali boy or girl marries someone from another religion, then they are ostracized.

8. Cross-cousin marriage is restricted among first generation, but it happens after two generation. That is ego's grandson can marry his cross cousin's granddaughter.

9. Remarriage or extramarital sex is not common among them.

10. Child marriage is restricted after Christianization.

Above all, the Mahali prefer and practice usual marriage by negotiation but their society permits other types of matting or widow marriage. Because they believe that, if these types of marriage are strictly prohibited, naturally illicit sexual intercourse will highly increase and vitiate the society. So, instead of usual marriage, other types of marriage are permitted by the society, which help to maintain peace in the society.

There is a certain age of marriage among the Mahali. The minimum age for marriage selected by the missionary is 18 years for girls and 22 years for boys. Before Christianization child marriage was very common among them. Then the age difference between husband and wife was 15-20 years. But at present the difference is 510 years. So the understanding is very well between husband and wife at present time.

The price of bride is very common among the Mahali people. It refers to the groom's giving of something to the bride's party. The amount of it is BDT 26 only. This price was same in the last decade. This giving process has not been changed at present time, because both boys and girls are equal earner. That is, when a girl goes to her husband's house, then her father loses an earner while her husband's family get a more. For this reason, bride price is given to the girl's father to fill up the lacking. But the amount of money had not been changed yet. There is no practice of dowry in the Mahali society. But in modern time they want dowry like their Hindu neighbor.

The Mahali society is patrilineal and patrilocal. In most cases the joint families break down by separation as soon as a son get married, due to economic pressure, female discord, lack of accommodation etc.

\subsection{Kinship}

Kinship plays an important role in the life of Mahali people. On certain occasions, such as construction of a new house, at the time of food shortage, at the time of birth, marriage and death ritual in a family, the members of the kin in the village usually the first person to volunteer their service to help and get priority invitation.

The Mahali system of kinship is of the kind of termed as "Descriptive System". But in case of ego's own generation, the kinship system can be termed as "Classificatory System" because a boy or a girl addresses his/her parallel or cross-cousins with the same term he/she addresses his/her own elder brother or sister. Mahali kinship terminology has been influenced by the Muslim, Hindu and the Santal kinship terminology. They have lost many of their own terms and have borrowed different terms from their neighboring communities, such as dada, didi, baba, ma etc. There is an especial system among the Mahali for selection of the name of son and daughter. The eldest son is given the name of parental grandfather and the second son is named after the maternal grandfather, the third that 
of the parental grandfather's brother and the fourth that of the maternal grandfather's brother. The daughters are given the names of equivalent female relations in the same order. If there is a Ghar-Jamai or a husband living in wife's father's house, then the naming order will be reversed, i.e. the name of the maternal side come first. The following diagram (Fig.5) illustrates the kingship terminology (Consanguine) used among the Mahalis in different generations and the Table 3 demonstrate the kinship terminology of the Mahalis in terms of address (Affinal relation).

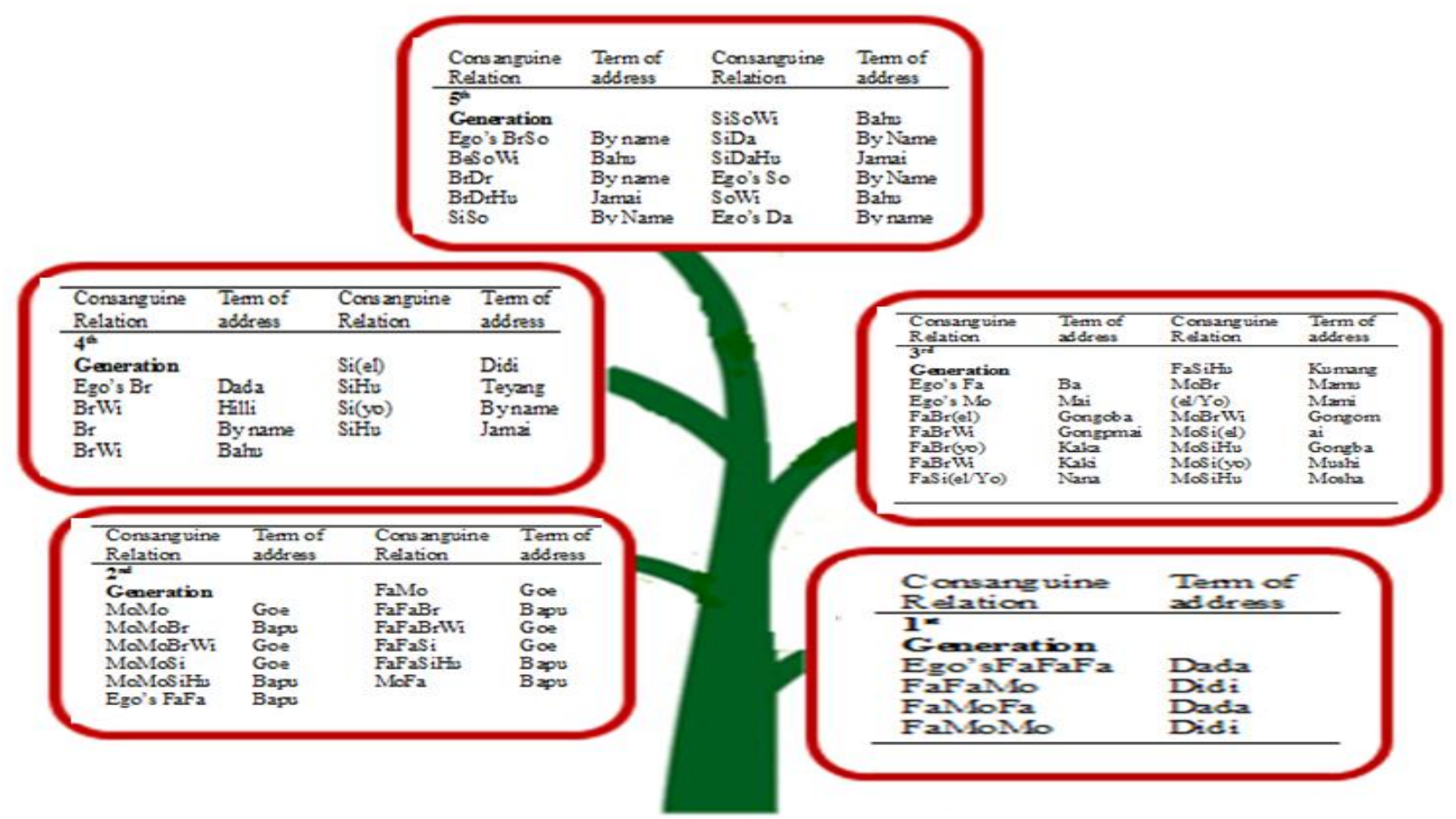

Fig-5. Kingship terminology of the Mahalis classified in terms of address (Consanguine relation) $[\mathrm{NB}: \mathrm{Fa}=\mathrm{Father}, \mathrm{Mo}=\mathrm{Mother}$, Wi $=\mathrm{Wife}, \mathrm{Hu}=\mathrm{Husband}$, el= elder, Yo= Younger, $\mathrm{Si}=\mathrm{Sister}, \mathrm{Br}=$ Brother, $\mathrm{So}=\mathrm{Son}$, Da $=$ Daughter``.

Source: Authors (Following Book: Ember and Ember (1994))

However, in Mahali society avoidance and joking relationships are also found as in other cultures, such as a man and his younger brother's wife and a woman and her husband's elder brother are strictly prohibited to come in contact with each other. Even a woman does not supply cooked food to her husband's elder brother by her own hand. On the other hand, as the husband's elder brother is the subject of a rigid taboo to a Mahali woman repression in one way leads to corresponding freedom with the husband's younger brother, who is considered to be a joking relation (Dhaulia).

Table-3. Kinship terminology of the Mahalis in terms of address (Affinal Relations)

\begin{tabular}{|c|c|c|c|c|c|}
\hline Affinal Relation & $\begin{array}{l}\text { Term of } \\
\text { address }\end{array}$ & Affinal Relation & Term of address & Affinal Relation & $\begin{array}{l}\text { Term of } \\
\text { address }\end{array}$ \\
\hline $\begin{array}{l}1^{\text {st }} \text { Generation } \\
\text { Ego's WiFa } \\
\text { WiMo } \\
\text { WiFaBr(el) } \\
\text { WiFaBrWi } \\
\text { WiFaBr(yo) } \\
\text { WiFaBrWi } \\
\text { WiMoBr }\end{array}$ & $\begin{array}{l}\text { Hoinhar } \\
\text { Hainhar } \\
\text { Gongohoinhar } \\
\text { Gongohainhar } \\
\text { Kakahoinhar } \\
\text { Kakihoinhar } \\
\text { Mamuhoinhar }\end{array}$ & $\begin{array}{l}\text { 2 }^{\text {nd }} \text { Generation } \\
\text { Ego's WiBr(el) } \\
\text { WiBrWi(se) } \\
\text { WiBrWi(ju) } \\
\text { WiBr(yo) } \\
\text { WiBrWi } \\
\text { WiSi(el) } \\
\text { WiSi(yo) } \\
\text { WiSiHu(el/yo) }\end{array}$ & $\begin{array}{l}\text { Baihar } \\
\text { Didi } \\
\text { Boyo } \\
\text { Sarelkara } \\
\text { Mesera } \\
\text { Ajnar } \\
\text { Saretkuri } \\
\text { Saru }\end{array}$ & $\begin{array}{l}\text { 3 }^{\text {rd }} \text { Generation } \\
\text { WiBrSo/WiSiSo } \\
\text { WiBrDa/WiSiDa }\end{array}$ & $\begin{array}{l}\text { By name } \\
\text { By name }\end{array}$ \\
\hline
\end{tabular}

[NB: Fa = Father, Mo=Mother, Wi = Wife, Hu = Husband, el= elder, Yo=Younger, Si= Sister, Br=Brother, So = Son, Da = Daughter ]

Source: Book: Anthropology (Ember and Ember, 1994) 


\subsection{Clan Organization}

The clan organization of the Mahalis is the important aspect of their social life. The clan can be defined as an exogamous group, the members of which are held to be related to one another by some common ties, may be belief in habitation of a common territory (Vidyarthi and Rai, 1976; Pels, 1999). Among the Mahalis clans are named after plants or animals. They have total 12 clans exactly to that of the Santal for which a debate regarding if both the Mahalis and the Santals were once same and have come from the same ancestor still continues. The 12 clans of the Mahalis are briefly illustrated in the following diagram (Fig.6).

When the Mahalis did not converted to Christianism then they used to show reverence for and not to destroy their totem objects. Now a days though they know about their clan objects but they do not obey the rules so strictly like before. At present time it is restricted that the members of the same clan cannot establish marital ties among them.

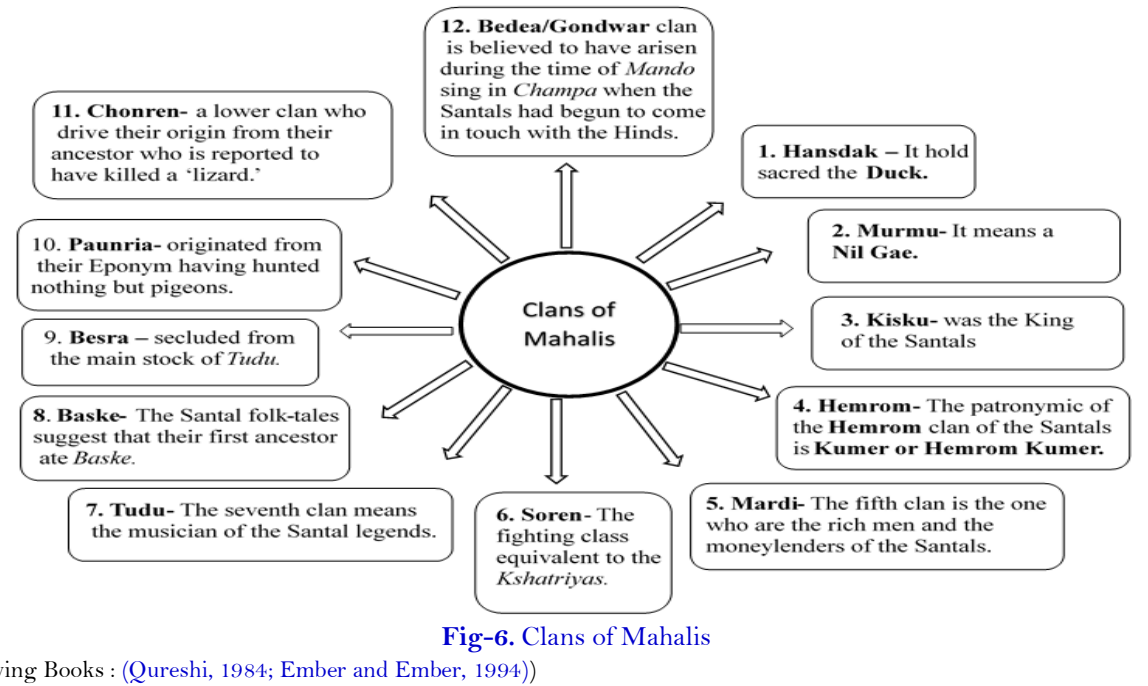

Source: Authors (Following Books : (Qureshi, 1984; Ember and Ember, 1994))

\section{LEADERSHIP PATTERNS}

The political life of the ethnic communities of Bangladesh reflects on paradoxical situation in which democracy and monarchy coexist. Every head of a community at different levels like clan, village and territory is generally honored, obeyed and accepted as the head of the group. There are two types of power structure among the Mahalis such as 1) Village power structure or the intra-village organization and 2) The Adibashi power structure or the inter-village organization.

\subsection{Intra-Village Power Structure}

Power is practiced here only within a single village, which consists of four persons- Manji, Paranik, Jogmanji and Godeth. Manji, the most eligible person who is treated as village head, is selected by the villagers. The major task of Manji is to settle dispute if any takes place in the village. Paranic, the second man in the power structure, is also selected verbally by the villagers. The third man, Jogmanji, mainly looks after any kind of feast or wedding if any take place in the village. Godeth is, in fact, a messenger or Chowkidar in Bengali. Whenever a Salish is scheduled to hold the Godeth inform all the villagers about the date and time of the Salish and gathered them in the Salish.

\subsection{Inter-Village Power Structure}

This is divided into Union level and Thana level. The Council Pargana Parishad is an elected body in the Union level. The head of this Parishad is Chairman or what they call Pargana, who is again assisted by five members or what they call Deshmajhi. The Thana Pargana Parishad is a level top to the Council Pargana Parishad. 
Tanore Pargana Parishad has no elected body but a selected committee consisting of 19 members which includes a President, a Vice-President, a General Secretary and other posts such as Cultural Secretary, Public Secretary, Women Secretary, Treasurer etc.

\subsection{Sources of Power}

There are two types of sources of power one is direct and another is indirect sources of power. The direct sources of power i.e. old age or experience, good economic condition, higher education and higher status, are those that directly influences in acquiring power. The indirect sources are relation with high administrative official, relation with NGOs and political influence.

Power is not heritable among the Mahalis rather than the villagers select the eligible person for the post. There has never been or any woman included either in the village power structure or in the Adivasi power structure. Women are not allowed to remain present in any Salish accept only she is a witness or involved in the dispute.

\section{RITUALS, RITES OF PASSAGE AND THE CONSTRUCTION OF MAHALI IDENTITY}

As mentioned before, the Mahalis are mainly Christians and they are the first community to become Christian. They fully comply with the Christian beliefs and practices. Beside the Sunday morning prayer they also conduct spatial prayer named Rojarimala which is observed through May. This prayer is for mother Merry. In Mondumala Mission, there is a Groto where an image of mother Merry is kept to say their prayers to her and then Holy Bible is read. The major religious ceremonies of the Mahalis are Paska Parb and Christmas. Paska Parb is, in fact, a memory of the resurrection of Jesus Christ. After fasting of forty days this ceremony takes place. This fasting of forty days is liberal for the kids below 14 years and the elders over 60 years of age. This forty days fasting generally starts in any Wednesday of February-March, which is fixed following the calendars. On the starting date, a prayer takes place in Mondumala Cristian Mission and then Father or Catechist master will again ashes over everyone’s head and will say, 'you have come out of land and will again end on land after death. God will again make you alive on the day of judgment'. Thus starts the 40 days of fasting. As Christians, Christmas is the biggest ceremony of Mahalis.

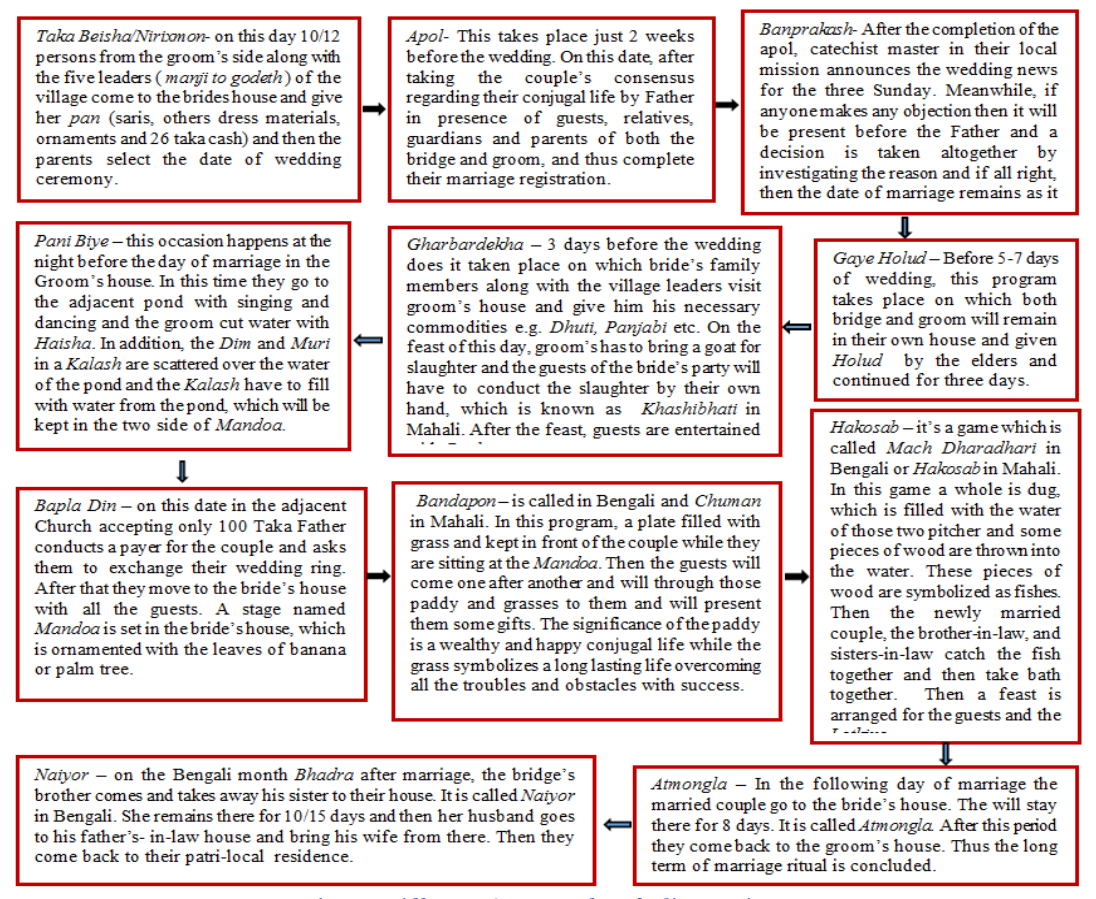

Fig-7. Different Stages of Mahali Marriage.

Source: Authors Filed Works (Mahali Marriage System) and Qureshi (1984) 
Father Alexander and Father Sebastian of Rohanpur Mission within 1950/52 baptized the Mahalis of Mondumala and Pachandar. But it was only in 1984 when Father A. Bayo established a community center in Mondumala with a view to helping the Christian of this village through some social welfare activities. At present Father Pierro comes here every Saturday from Dingaduba Mission and leaves on Sunday after conducting the weekly Sunday Prayers.

Among the Mahalis marriage is occurred by the negotiation of the riber haram or riber buri. He/she is appointed by any of the site and he has the responsibility of maintaining liaison between the two sides. There are different stages of Mahali marriage which are briefly explained in the diagram (Fig.7).

\section{RELIGIOUS SYNCRETISM}

The prime objective of this study is to know how the Mahalis cope up with their changing socio-cultural situations because of their religious syncretism from Mahali to Christian. "Syncretism is the combining of different beliefs, while blending practices of various school of thought". From this study we can say that, the process of sociocultural adjustment of the Mahalis is known as Religious syncretism because they have changed their traditional religion and convert to Christianity. Actually they follow a mixed culture. Here we can follow Mullins. He says "Syncretism is usually understood as combination of elements from two or more religious traditions, ideologies or value systems. In the social sciences, this is a neutral and objectives term that is used to describe the mixing of religions as a result of cultural contract."

\section{CONCLUSIONS}

Beside the mainstream population there are about 50 tribal communities in Bangladesh. They have their own culture and lifestyle. In spite of having scholar's debate regarding their settlement in Bangladesh, they are the inhabitants of this country. Some ethnic communities are registered and some are not. 'Mahali' is one of the nonregistered community who have migrated to Bangladesh a long time ago. Initially, the Mahali people had the belief on traditional religion like the 'Hindu'. At that time their culture and life style was different from present culture. It has been changed for various reasons. Impact of Christianization is one of them. Their life style has been changed in many spheres for this conversion, which creates huge deviations in their culture as well as social structure as the religion plays an important role on human life and society. However, it is related to human existence. That's why we have explored the role of religion over the Mahali Christians. The personal or material benefit plays vital starring role behind their conversion rather than divine relief. Actually, the Mahalis accept the attractive offers of the missionary due to their economic vulnerability. By their conversion they just create a mixed situation. In academic language this is called Religious syncretism. Though religion is a belief system but among the Mahalis it become a tool for the development of their fate.

In this context they have fairly left their traditional beliefs. Their consciousness about their education has been increased for Christianization. Now most of them are literate. Marriage rules have also been changed partially. At present they full filled their main part of marriage in the church and also do not practices the polygamous marriage. Though the Mahalis have adapted themselves to many Christian beliefs and rituals, but there had not occurred any radical change in their social economic and political organization. After Christianization their main occupation have not been changed, rather their preserving such a rich trend and heritage of craft making. They also practiced their traditional power system in modern time.

The priorities of needs are (1) the Mahalis have not get any major help from the government. They should be assumed by the government that all institutional and infrastructure supports will be extended in building their social, economic, political and cultural life. (2) A permanent commission consisting of expertise from various disciplines should actively look after the development activity of Mahali community. (3) The historical evaluation of Mahali society has its own identity. It should be preserved and further development in its own natural course. So 
the safe-guard of the community from the interference of other competitive community should be guaranteed. (4) The Mahalis are professionally crafts maker. So they should be provided with modern concept and technical knowledge regarding their craft making, with a purpose to make them relined. (5) The trend of increase drinking of Pachani is the cause of heavy financial loses for the Mahalis. They should be given modern health ideas are motivated to get rid of these problems very quickly.

Funding: The authors acknowledge the assistance and cooperation of Department of Sociology, University of Rajshai supporting this study.

Competing Interests: The authors declare that they have no competing interests.

Contributors/Acknowledgement: The authors gratefully acknowledge the cordial help and cooperation of the villagers of Pachandar and Mondumala villages.

\section{REFERENCES}

Ahsan, A., 1998. The Santals of Bangladesh. Fulgeria, Dist. Midnapur, W.B.: Institute of Social Research \& Applied Anthropology; Calcutta: Distributors, Subarnarekha, India. pp: 344.

Dalton, E.T., 1872. Descriptive ethnology of Bengal. Calcutta: Office of the Superintendent of Government Printing.

Ember, C.R. and M. Ember, 1994. Anthropology. 7 th Edn., N.J., USA: Prentice-Hall. Inc. pp: $307-350$.

Gomes, G.S., 1988. The Paharias: A glimpse of tribal life in Northwestern Bangladesh. Bangladesh: Caritas.

Hoffman, 1950. Encyclopedia Mundarica. Patna: Government Press, 13.

O’Malley, L.S.S., 1938. Bihar district Gazzetters-santal parganas. 2nd Edn., Bihar, Patna, India: Indian Civil Cervice, Superintendent. Government Printing. pp: 108-182.

Pels, P., 1999. The rise and fall of the Indian aborigines, orientalism, anglicism, and the emergence of an ethnology of India.

Colonial Subjects. Essays in the Practical History of Anthropology. Netherlands: Amsterdam Institute for Social Science Research (AISSR), University of Amsterdam. pp: 82 - 116.

Qureshi, M.S., 1984. Tribal cultures in Bangladesh, Bangladesh: Institute of Bangladesh Studies (IBS), Rajshahi University. $5: 158-167$.

Rao, K.V.R., 2006. The dravidian problem. Retrieved from http://www.allempires.com/forum/forum_posts.asp?TID=10911.

Ray, M. and C. Biswas, 2013. Migration at Border: An anthropological study on cross-border Oraons in North 24-Parganas, W.

Bengal, India. Mediterranean Journal of Social Sciences, 4(13): 683-690. View at Google Scholar | View at Publisher

Risley, H.H., 1891. The tribes and castes of Bengal. Calcutta: Bengal Secretariat Press, 2.

Roy, S.C., 1912. The Mundas and their country. Calcutta: Jogendra Nath Sarkar at the City Book Society.

Roy, S.C., 1912. Mundas and their country. Calcutta: City Book Society.

Roy, S.C., R. Bahadur and P.D. Sharma, 1980. The passing scene of Chotonagpur: Sarat Chandra Roy commemorative volume. Ranchi: Mairyee Publications.

Vidyarthi, L.P. and B.K. Rai, 1976. The tribal culture in India. New Delhi: Concept Publishing Company

Views and opinions expressed in this article are the views and opinions of the author(s), International Journal of Asian Social Science shall not be responsible or answerable for any loss, damage or liability etc. caused in relation to/arising out of the use of the content. 